TARNOWSKIE STUDIA TEOLOGICZNE 34 (2015) nr 1, s. 67-82

http://dx.doi.org/10.15633/tst.1564

\author{
ks. Janusz Pycia ${ }^{1}$ \\ PADERBORN
}

\title{
Idea zmartwychwstania w najstarszych religiach Bliskiego Wschodu
}

Pytania z zakresu eschatologii, szczególnie eschatologii indywidualnej, towarzyszą człowiekowi niezależnie od czasu i kultury, w której żyje i w której został wychowany. Ponieważ kultury poszczególnych ludów zasadniczo różnią się między sobą, zawierając niekiedy także spójności odnośnie do niektórych kwestii, ciekawe wydaje się zatem prześledzenie odpowiedzi na te pytania w poszczególnych kulturach Bliskiego Wschodu, poprzedzających najpełniejszą z odpowiedzi na temat życia po śmierci, zawartą w religii chrześcijańskiej, która przecież nie formowała się w izolacji, lecz w kontakcie z innymi religiami.

Celem niniejszego opracowania jest wskazanie znaczenia wiary w zmartwychwstanie w najstarszych religiach Bliskiego Wschodu. W sposób szczególny analizie zostaną poddane wierzenia w kultach Mezopotamii, Egiptu, Fenicji oraz Persji, przy uwzględnieniu występujących analogii z tradycją biblijną.

\section{Tradycja mezopotomska}

Jako miejsce powstania kultury Mezopotamii wskazuje się obszar północnego Szanidaru. Jeśli chodzi zaś o datację jej początków, to przyjmuje się okres między 50 a 10 tysięcy lat przed Chrystusem². W mitologii mezopotamskiej

1 Ks. Janusz Pycia, kapłan diecezji tarnowskiej. W roku 2011 ukończył studia licencjackie na UPJPII w Krakowie Wydział Teologiczny Sekcja w Tarnowie. Od 2011 roku pracuje w duszpasterstwie niemieckim w diecezji Paderborn.

2 W ciągu dalszych wieków osadnicy tych terenów przenieśli się ku południowi nad Zatokę Perską, gdzie kontakt mieszkańców południa z północnymi obszarami doprowadził do wytworzenia wspólnej, jednolitej kultury Mezopotamii, zwanej kulturą Obeid (Ubajd) (4500-3300 przed Chr.), tworzącej po raz pierwszy budowle sakralne. W dalszej kolejności (połowa IV tysiąclecia) wpływ na omawianą kulturę wywarli Semici oraz w ogromnej mierze Sumerowie, których wielkim osiągnięciem było m.in. rozpowszechnienie pisma. Dalsze kształtowanie kultury w Mezopotamii odbywało się za dynastii akadyjskiej, łączącej elementy sumeryjskie i akadyjskie. Po jej upadku ważną rolę odgrywali Amoryci i Elamici, którzy podzieli państwo między siebie, oraz dynastia babilońska, w dużej mierze kształtująca sztukę i literaturę Mezopotamii. Nie spo- 
ważną rolę odgrywała bogini wojny i miłości - Isztar. Na skutek pychy została uwięziona $\mathrm{w}$ świecie podziemnym, a jej powrót do życia stał się możliwy dopiero po oddaniu przez nią jej męża Tammuza w ręce rządzącej światem podziemnym bogini Ereszkigal. Dominujący jest w tym przypadku motyw ofiary na rzecz panującego w ,zaświatach” bóstwa, w celu wyproszenia powrotu do wcześniejszego życia ${ }^{3}$.

Temat powrotu z krainy umarłych do życia występuje też w wierzeniach syryjskich w historii bogini Isztar, zakochanej w urodziwym Adonisie, niestety bez wzajemności. Aby uciec przed tą nieszczęśliwą miłością, Adonis udaje się do krainy umarłych. Za nim podąża Isztar, bogini płodności, co powoduje, że cała przyroda obumiera, by narodzić się na nowo w chwili powrotu bogini na ziemię ${ }^{4}$.

Pewną koncepcję dążenia do nieśmiertelności poprzez ucieczkę z zaświatów ukazuje jeden $\mathrm{z}$ najstarszych utworów literackich na świecie, prawdopodobnie z IV tysiąclecia przed Chr., zachowany w wersji akadyjskiej z III tysiąclecia przed Chr. epos o Gilgameszu ${ }^{5}$. Opowiada on historię króla Uruk (ok. 2800 przed Chr.), szukającego „krainy życia”, nieśmiertelności w celu uniknięcia śmierci własnej i swego przyjaciela Enkidu. Wynik jego poszukiwań znajduje swoje podsumowanie w następujących słowach: „«O, Gilgameszu! Na co ty się porywasz? Życia, co go szukasz, nigdy nie znajdziesz!» (Tabl. VIII, X); «Kiedy bogowie stworzyli człowieka, śmierć przeznaczyli człowiekowi, życie zachowali

sób także pominąć roli Kasytów, najdłużej panujących w dziejach Mezopotamii, którzy opanowali jej południowe obszary i przejęli kulturę sumeryjsko-akadyjską. Swoje piętno pozostawiła także Asyria, zdobywająca od XIV wieku coraz to większe strefy wpływów i konfrontująca się z pojawiającą się na arenie dziejów kulturą Medów, Persów oraz państwem Izrael. Warto tu wspomnieć o nieocenionej dla poznania kultury i dziejów Mezopotamii roli ostatniego władcy imperium asyryjskiego, Asurbanipalu (Aššur-bāni-apli) (669-629 przed Chr.), który zgromadził dużą liczbę tekstów historycznych, urzędowych, religijnych, literackich i naukowych w ogromnej bibliotece w Niniwie. Po tym okresie decydujący wpływ na kulturę Mezopotamii odgrywała Babilonia, której budowla ziggurat Etemenanki - „Fundament nieba i ziemi” - stała się prototypem biblijnej wieży Babel. W tym czasie dochodzą do głosu także wydarzenia związane z okresem niewoli babilońskiej w dziejach Izraela. Schyłek Babilonii to także czas zaniku wielowiekowej kultury sumeryjsko-akadyjskiej. Po tym okresie Mezopotamia, a więc i jej kultura, stała się częścią wielkiego imperium perskiego. Zob. T. Jelonek, Kultura mezopotamska a Biblia, Kraków 2009, s. 5-26.

3 Na temat związanego z postacią Tammuza święta zmarłych, w czasie którego wierzono, że zmarli wychodzą na krótki czas ze świata podziemnego, by przyjmować dary ofiarne, zob. szerzej: A. Sołtysiak, Religie Mezopotamii, [w:] Religie starożytnego Bliskiego Wschodu, red. K. Pilarczyk, J. Drabina, Kraków 2008, s. 166-167.

4 Zob. http://www.opoczno-top.pl/artykul,Zmartwychwstanie w mitach i religiach, 11998. html (02.05.2014). Artykuł ukazał się również w „Tygodniku Opoczyńskim” 29.03.2013, nr 13 (820).

Gilgamesz. Epos starożytnego Dwurzecza, tł. R. Stiller, Warszawa 1980, s. 102. 


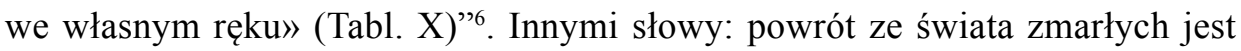
niemożliwy, śmierć jest ostateczna i nieodwracalna ${ }^{7}$.

Epos o Gilgameszu wskazuje jednak, że zdarzało się czasami, iż sami bogowie pozwalali wyjść zmarłym na powierzchnię ziemi, aby umożliwić kapłanowi wywołanie cienia - ducha zmarłego. Celem było uzyskanie wskazówek dla żyjących, czy też określonych informacji. Wizyty te jednak miały raczej charakter krótkotrwały i sporadyczny. Zdarzało się, że jakiś duch zmarłego nie wracał w zaświaty, ale wtedy był zmorą dla żyjących, powodując wiele nieszczęść i zmartwień. Według wierzeń mezopotamskich, jeśli rodzina nie dbała o zmarłego, to jego cień stawał się zły i uciekając z podziemi, straszył i dręczył ludzi ${ }^{8}$.

Pewien motyw zmartwychwstania, ale rozumianego jedynie metaforycznie, widziany jest $\mathrm{w}$ odniesieniu do zajmującego ważne miejsce w panteonie bóstw mezopotamskich boga Marduka, a właściwie do jego kultu, który zwłaszcza po zniszczeniu Babilonu w roku 689 przed Chr. przez króla asyryjskiego Sennacheryba (Sîn-ahhē-erība) wiele stracił na znaczeniu. Jednak próba wymazania kultu Marduka zakończyła się niepowodzeniem, bo już syn wspomnianego wyżej władcy Asyrii dokonał jego rehabilitacji. W tym znaczeniu przeżył Marduk po katastrofie roku 689 przed Chr. metaforyczne zmartwychwstanie. Dopatrywanie się w tym przypadku jakiegokolwiek podobieństwa w odniesieniu do biblijnego rozumienia zmartwychwstania byłoby jednakże absurdalne9 .

Niewątpliwie znaczący wkład w kształtowanie systemu wierzeń religijnych Mezopotamii mieli Sumerowie. Natura ludzka według nich była słaba, a co za tym idzie szczęście po śmierci nie mogło być jej udziałem, co najwyżej monotonny spokój w szarości i ubóstwie. W dużej mierze te idee przejęli także Babilończycy

6 C. S. Bartnik, Dogmatyka katolicka, t. 1, Lublin 1999, s. 352.

Wspominając wątek władców mezopotamskich, nie sposób pominąć wyjątkowych, bo niemających żadnych analogii wcześniejszych ani późniejszych monumentalnych grobów królewskich z Urit, które jednak mogą się łączyć z istnieniem już wówczas jakiejś wiary (opowieść o śmierci Ur-Nammu) w zamieszkiwanie przez władców pałaców świata podziemnego. Por. A. Sołtysiak, Religie Mezopotamii, dz. cyt., s. 127.

Trzeba przyznać, że mieszkańcy Mezopotamii w III tysiącleciu przed Chr. nie poświęcali zbyt dużej uwagi światu zmarłych. Nie oznacza to jednak braku jakiegokolwiek zainteresowania tym tematem. Jako przykład można podać zwyczaj troszczenia się, przynajmniej raz w roku, w czasie święta zmarłych o pokarm i napój dla nich. Troska ta wynikała z przekonania, że brak pożywienia może zmusić zmarłych do konieczności żywienia się gliną i błąkania się po Podziemiu. Większy nacisk w kulturze Mezopotamii tamtego okresu kładziono na życie ziemskie, którego ważnym elementem była praca, ta zaś miała ostatecznie prowadzić do zapewnienia przychylności bogów. Por. A. Sołtysiak, Religie Mezopotamii, dz. cyt., s. 132-133.

8 Zob. G. M. Baran, Los człowieka po śmierci w wierzeniach ludów ościennych dawnego Izraela, ,Scripturae Lumen” 2010 nr 2, s. 140-141.

9 Szerzej zob. K. H. Golzio, Der Tempel im Alten Mesopotamien und Seine Parallelen in Indien. Eine Religionshistorische Studie, Hamburg 1983, s. 81-89 (Beihefte der Zeitschrift für Religions- und Geistesgeschichte, 25). 
i Asyryjczycy. Stąd nie jest zaskoczeniem również i u nich taka pesymistyczna, ponura wizja zaświatów, rządzonych przez boga Nergala i jego żonę Ereszkigal ${ }^{10}$.

Na podstawie wyżej wymienionych świadectw można stwierdzić, że kulturze Mezopotamii nie była obca wiara w nieśmiertelność bóstw, jak i idea cyklicznego odrodzenia przyrody, związanego z przebudzeniem się bóstw płodności ${ }^{11}$. Podobnie ma się rzecz z przekonaniem o pewnej formie ciągłego istnienia zmarłych w podobnych grobowi podziemiach.

Wydaje się niezaprzeczalny fakt, że wpływy kultury mezopotamskiej można odnaleźć w tradycji biblijnej, wymieniając chociażby redakcję niektórych ksiąg biblijnych, np. Pięcioksięgu, jak i początek interpretacji słowa JHWH w postaci Talmudu i Kabały oraz uformowanie praktyk religijnych judaizmu, chociażby tych dotyczących studium Tory. Spotkanie tradycji biblijnej z kulturą Mezopotamii, zwłaszcza w czasach niewoli babilońskiej, zaowocowało dalszym rozwojem myśli biblijnej, prowadząc do osadzenia wiary w JHWH w konkretne ramy kultowe, zwane judaizmem ${ }^{12}$.

\section{Kultura egipska}

Dosyć wcześnie, bo na około XVII wieku przed Chr. datuje się pierwsze nam znane kontakty Żydów z Egiptem. Miało to nastąpić przy okazji migracji Hyksosów, plemion zachodnioazjatyckich na teren Egiptu, po rozbiciu ich państwa przez Egipcjan ${ }^{13}$. Aby zrozumieć kulturę egipską, trzeba przyjrzeć się bliżej warunkom, w jakich ona powstawała. W cywilizacji egipskiej należy wyróżnić okres prehistoryczny (predynastyczny) oraz czasy dynastyczne. Te natomiast sięgają trzeciego tysiąclecia przed Chr., kiedy to nastąpiło zjednoczenie regionu delty (Egiptu Dolnego) i doliny Nilu (Egiptu Górnego) za panowania Narmera (gr. Menesa) ${ }^{14}$.

W czasie II dynastii, wchodzącej w skład okresu wczesnodynastycznego (tynickiego), ośrodkiem państwowym stał się Memfis. Wtedy też doszło do kryzysu, załagodzonego przez faraona Chasechemui (2734-2707 przed Chr.), który przyczynił się do uregulowania sytuacji gospodarczej, politycznej oraz religijnej kraju. Warto tu wspomnieć o następującym w tym okresie procesie unifikacji religii egipskiej. Faraon uznany został za potomka boga słońca - Re i uosobieniem

10 Zob. O. R. Gurney, The Sultantepe tablets (continued): VII. The myth of Nergal and Ereshkigal, „Anatolian Studies” 10 (1960), s. 105.

11 Jako przykład można tu podać liczne pieśni i teksty, mówiące o Inannie i Dumuzim, a nawiązujące do cyklu zmieniających się pór roku. Szerzej zob. A. Sołtysiak, Religie Mezopotamii, dz. cyt., s. $134-136$.

12 Szerzej zob. T. Jelonek, Kultura mezopotamska ..., dz. cyt., s. 89-110.

13 Zob. L. Mrozewicz, Historia powszechna. Starożytność, Poznań 1999, s. 45-46.

14 Zob. B. J. Kemp, Starożytny Egipt. Anatomia cywilizacji, tł. J. Aksamit, Warszawa 2009, s. 25; M. Marciniak, Historia starożytnego Egiptu, [w:] Starożytny Egipt, red. A. Szczudłowska, Warszawa 1978, s. 77. 
boga nieba - Horusa. Bardzo ciekawe jest również odkrycie w grobie jednego z urzędników państwowych, służących za panowania faraona Dena, wzmianki o mumifikacji zwłok. Może to świadczyć o kształtującej się wówczas wśród Egipcjan wierze w zachowanie ciała po śmierci ${ }^{15}$. W tym okresie następuje także przejście od małych podziemnych grobów do dużych budowli naziemnych, zwanych mastab ${ }^{16}$.

W czasie Starego Państwa (2675-2170 przed Chr.) nastąpiła ekspansja Egiptu na tereny Nubii, ziem półwyspu Synaj, później także Libii. Wynikało to z niesamowitego rozwoju państwa egipskiego w okresie IV dynastii, który można śmiało nazwać latami świetności. W tym czasie zaczęto budować charakterystyczne dla tej cywilizacji budowle religijne, tzw. piramidy ${ }^{17}$. Pierwszą z nich wzniósł Imhotep dla faraona Neczericheta, znanego pośmiertnie jako Dżesar (egip. „władczy”). Tworzyła ona ogromny kompleks grobowy, wśród którego wyróżniała się piramida schodkowa w Sakkara ${ }^{18}$. Budowa tego typu budowli zapewne nie była przypadkowa, ale wynikała z panującego już wtedy powszechnie przekonania o bóstwie faraona.

Niestety, rozwój i powodzenie kultury Egiptu nie trwały nieprzerwanie. Jako przykład można tu podać tzw. Pierwszy Okres Przejściowy (2181-2133 przed Chr.), w którym rządzone przez nomarchów państwo rozpadło się na poszczególne dzielnice. Dopiero ponowne ich zjednoczenie przez władcę Teb, Mentuhotepa II ok. 2050 roku przed Chr. pozwoliło Egiptowi na dalszy rozwój kulturowy ${ }^{19}$. Jednakże i on został przerwany kryzysem kultury egipskiej w latach 1786-1567 przed Chr., po którym w latach 1550-1070 przed Chr. (tzw. Nowe Państwo) nastąpił kolejny czas rozwoju kultury egipskiej, i to naprawdę na wielką skalę. W sferze religijnej doszło do zmiany czczonych bóstw, jak choćby w XIV wieku przed Chr. wprowadzenie kultu boga Atona zamiast boga Amona oraz stworzenia po drugiej stronie Nilu tzw. Doliny Zmarłych, będącej nekropolią zmarłych władców. Dzieje Egiptu przypominają nieustanną sinusoidę, a więc po kolejnych latach rozwoju nadeszły „lata chude” (1085-664 przed Chr.), gdzie doniosłą rolę odgrywały dynastie libijskie i kuszyckie. W tym czasie dochodzi do zbrojnego zajęcia Dolnego Egiptu, w tym znaczącego miasta Memfis przez Asyrię. Po objęciu władzy przez Psametycha I (664-610 przed Chr.) Egipt ponownie zyskał na sile i pokusił się nawet o opanowanie Bliskiego Wschodu, w czym przeszkodzili mu

15 Szerzej zob. N. Grimal, Dzieje starożytnego Egiptu, Warszawa 2004, s. 58-72; T. A. H. Wilkinson, Early dynastic Egypt, London-New York 1999, s. 69-79, 225.

16 Zob. T. A. H. Wilkinson, Early..., dz. cyt., s. 36-38; N. Grimal, Dzieje..., dz. cyt., s. 58-72.

17 Szerzej zob. N. Grimal, Dzieje..., dz. cyt., s. 116-132.

18 Zob. L. Zinkow, Imhotep - ,Twórca cywilizacji”, „Episteme. Czasopismo Naukowo-Kulturalne" 2012 nr 16 t. 1, s. 9.

19 Zob. S. Arnold, W. Kurkiewicz, A. Tatomir, W. Żurawski, Dzieje świata. Chronologiczny przegląd ważniejszych wydarzeń, Warszawa 1990, s. 16-17. 
Persowie (525 r. przed Chr.) $)^{20}$. Można z całą pewnością stwierdzić, że od samego początku aż do wieku IV przed Chr. Egipt zachował mimo wzlotów i upadków integralność terytorialną oraz kulturową.

Dopiero wkroczenie Aleksandra Wielkiego otworzyło nowy rozdział w kulturze Egiptu znajdującej się pod wpływem greckiej kultury i religii, która doprowadziła do wprowadzenia wielu nowych idei z obcego Egipcjanom kręgu kulturowego. Nie można jednak zapomnieć o ogromnym wkładzie, jaki helleńscy władcy wnieśli w rozwój Aleksandrii, jako ośrodka myśli, co z pewnością nie pozostało obojętne dla kultury Egiptu ${ }^{21}$. Śmierć Aleksandra Wielkiego (323 przed Chr.) otworzyła możliwość przejęcia władzy w Egipcie przez Imperium Rzymskie, a co za tym idzie wpływania na jego kulturę i religięe22.

Jedną z bardziej znanych pierwszych recenzji kultury egipskiej odnaleźć można u Herodota, dla którego kultura i religia Egiptu znacznie wyróżniały się pośród innych ówcześnie istniejących ${ }^{23}$. W kulturze czasów prehistorycznych Egiptu, podobnie zresztą jak i u innych kultur Bliskiego Wschodu, występuje wiara w wędrówkę w zaświaty, na którą należało zmarłych odpowiednio wyposażyć, dostarczając im pożywienie, ale obok tego także wyposażenie umożliwiające łowy, co już tak powszechne we wszystkich kulturach nie było. Zmarły udawał się na zachód, gdzie niejako słońce codziennie „umiera”. Zwłaszcza okres gerzeński ${ }^{24}$ charakteryzował się znacznym stopniem rozwoju wiary $\mathrm{w}$ życie pozagrobowe, która przejawiała się w zapewnieniu zmarłemu wszystkiego, co było niezbędne do godziwego życia po śmierci. Groby zmarłych stanowiły repliki siedzib ziemskich, bogato urządzonych. Za królestwo zmarłych odpowiadał według egipskiej kosmologii Ozyrys ${ }^{25}$. Jako władca podziemnego świata, uosabiający śmierć i zmartwychwstanie, osądzał dusze zmarłych. Jeśli chodzi natomiast o próby wyjaśnienia jego pochodzenia, to według niektórych na jego charakterystykę wpłynęło kilka pomniejszych postaci o różnych cechach. Jako jedną z nich wymienia się lokalnego monarchę, cieszącego się szacunkiem poddanych, a po śmierci przez nich ubóstwianego. Na potwierdzenie tego wyjaśnienia wymienia się wizerunki Ozyrysa w ludzkiej postaci. Według innych hipotez, odwołujących

20 Szerzej zob. Religie starożytnego Bliskiego Wschodu, dz. cyt., s. 21-23; A. Ćwiek, Religia Egiptu, [w:] Religie starożytnego Bliskiego Wschodu, dz. cyt., s. 33-34.

${ }^{21}$ Zob. B. Bravo, E. Wipszycka, Historia starożytnych Greków. Okres hellenistyczny, t. 3, Warszawa 1992, s. 199-204.

22 Zob. I. Shaw, The Oxford history of ancient Egypt, Oxford 2000, s. 388-389; B. Bravo, E. Wipszycka, Historia ..., dz. cyt., s. 20-24.

23 Por. Herodot, Dzieje, tt. S. Hammer, Warszawa 1959, s. 134.

24 Nazwa pochodzi od El-Gerza, znajdującej się kilka kilometrów od innego stanowiska archeologicznego: Mejdum. Zob. N. Grimal, Dzieje..., dz. cyt., s. 58-72; T. A. H. Wilkinson, Early..., dz. cyt., s. $36-38$.

${ }_{25}$ Szerzej zob. N. Grimal, Dzieje..., dz. cyt., s. 58-72; T. A. H. Wilkinson, Early..., dz. cyt., s. $36-40,51-52$. 
się do znanego z Tekstów piramid z czasów Starego Państwa mitu ozyriackiego, wspomniany bóg był postacią historyczną, władcą delty Nilu, którego panowanie było tak wspaniałe, że zapisało się w przekazach jako „złoty wiek”. Popularność tego mitu znalazła swoje odzwierciedlenie także w działalności kapłanów, którzy posługiwali się nim w celu obrony oficjalnej wiary. Według tego mitu miał on być synem bóstw Geba i Nut i posiadać troje rodzeństwa: Seta, Izydę i Nefrydę. Już jako władca, wraz ze swoją żoną i siostrą zarazem - Izydą podjął się troski o lud, ustanawiając dla niego prawa, wyjaśniając mu tajniki uprawy roli i wytwarzania narzędzi. Taki sposób postępowania nie podobał się jednak jego zawistnemu bratu, Setowi, budząc w nim zawiść. By pozbyć się Ozyrysa zbudował wspaniałą skrzynię - sarkofag, a następnie podstępem zwabił go do niej, by się w niej położył. Gdy ten to uczynił, zamknął skrzynię i wrzucił ją do Nilu, topiąc wraz z nią swego brata. W chwili śmierci dusza Ozyrysa uciekła, chowając się na księżycu przed goniącym ją Setem. Ten jednak nie dał za wygraną i przybierając postać byka bądź gazeli, pożarł księżyc wraz duszą brata. Dowiedziawszy się o śmierci męża, Izyda udała się wraz z Anubisem - bogiem o głowie szakala, patrona mumifikacji na poszukiwanie jego ciała. Dopiero w Fenicji natrafiła na sarkofag swego męża, który przez niewiedzę został wykorzystany jako kolumna pałacowa. Według wersji o poćwiartowaniu zwłok Ozyrysa ${ }^{26}$ Izydzie udało się znaleźć prawie wszystkie części ciała, z wyjątkiem fallusa, połkniętego przez rybę, którego musiała przy składaniu ciała zastąpić gliną z woskiem. Starożytni widzieli w tym pierwszy akt mumifikacji. Scaleniu ciała Ozyrysa towarzyszyły zaklęcia i następujące lamenty pogrzebowe: „Powstań, odwróć się Ozyrysie, to ja Izyda przybyłam, aby cię zebrać i dać serce twemu ciału. [...] Idź i przybądź, obudź się i śpij, ponieważ ty trwasz w życiu. Podnieś się, popatrz na to, powstań. [...] powstań i usiądź, zrzuć ziemię, która jest na tobie [...]. Pozbieraj swe kości, zbierz swe członki, wybiel twe zęby, weź swe cielesne serce, zrzuć proch, który jest na tobie" ${ }^{27}$. Po tych praktykach miało nastąpić ożywienie ciała Ozyrysa, który następnie ze swoją żoną Izydą począł swego mściciela - Horusa. Ozyrysowi nie dane było jednak pozostać w świecie żywych, zmuszony był zstąpić w zaświaty, zasiadając w nim jako władca i sędzia zmarłych ${ }^{28}$. Mit ten wyraża więc żywą wiarę w możliwość ożywienia ciała zmarłego i jego, choć ograniczonego czasowo, powrotu do świata żyjących. Naturalnie trzeba stwierdzić, że wiara w zmartwychwstanie ciała w ujęciu egipskim ma tutaj odniesienie jednostkowe, a nie powszechne, choć była zaczątkiem do pogłębienia refleksji na ten temat w przyszłych wiekach, aż do wiary we wniebowstąpienie zmarłych.

\footnotetext{
${ }^{26}$ Mowa tu o ptolomejsko-rzymskiej wersji mitu o Ozyrysie. O innych wersjach jest mowa poniżej.

27 Teksty piramid, tł. M. Marciniak, cyt. za: Starożytni Egipcjanie, red. J. Cieślewska, Warszawa 2007, s. 118 (Mitologie Świata).

28 W powyższym tekście została przedstawiona wersja wg Tekstów piramid. Szerzej zob. Starożytni Egipcjanie, dz. cyt., s. 72-75, 109-111, 118.
} 
Bardzo ważne dla wiary w zmartwychwstanie jest całościowe spojrzenie na człowieka, jako istoty składającej się z elementu materialnego i duchowego zarazem. W przypadku wierzeń egipskich ma się do czynienia z bardziej zróżnicowanym podziałem w człowieku na ciało fizyczne (chet), które przez swą nietrwałość nie mogło być „mieszkaniem” dla jego pięciu duchowych elementów. Do nich należy zaliczyć tzw. cień (szut); ach, który utożsamia się z duszą; siłę witalną ka; niematerialny byt $k a$, powracający do ciała po zakończonej mumifikacji oraz imię człowieka (ren) wyrażające jego przeznaczenie ${ }^{29}$.

Egipcjanie posiadali bardzo rozbudowany i bogaty rytuał i kult pogrzebowy. Bardzo ważnym jego elementem był proces mumifikacji. Niestety, nie jest znany egipski opis tych zwyczajów, lecz z pomocą przychodzą tu tacy twórcy greccy, jak: Herodot, Diodor, Plutarch, Porfiriusz, którzy przekazują informacje na ten temat. Wiadomości te ukazują przede wszystkim cel i znaczenie symboliczne tego zabiegu, natomiast czysto technicznych informacji na temat balsamowania zwłok zmarłych dostarczyły współczesne badania mumii. Po spreparowaniu zwłok, umieszczano je w komorze grobowej zamykanej zaporą z kamienia. Wart uwagi jest także opis kaplicy grobowej, której kształt zmieniał się na przełomie wieków, przyjmując także w pewnym czasie formę krzyża. Kaplica była miejscem przyjmowania odwiedzin przez zmarłego. Nad drzwiami umieszczano tytuły i wizerunki zmarłego. Po drugiej stronie (na ścianie zachodniej) znajdowały się „Ślepe wrota” w różnej liczbie, pozwalające korzystać zmarłemu i rodzinie z ofiary. Na pozostałych ścianach znajdowały się malowidła przedstawiające sceny z życia i pielgrzymkę do świętych miast ${ }^{30}$.

Piramidy były nie tylko miejscem spoczynku i kultu zmarłego, ale także świadectwem wierzeń. Dzięki umieszczanym na ich ścianach tekstom nagrobnym możliwe staje się poznanie egipskiego systemu wierzeń dotyczącego zaświatów. Do tekstów tych są zaliczane: Teksty piramid, Teksty sarkofagów. Te ostatnie wywarły znaczący wpływ na różnice w redakcjach Księgi umarłych, których teksty miały pomóc zmarłemu w osiągnięciu oczyszczenia i przemiany w pewnego rodzaju ciało astralne. Jeśli mowa o Egipcie, to nie może zabraknąć wzmianki o piśmie obrazkowym, zwłaszcza tym odnalezionym w licznych grobach. Na podstawie wyżej wymienionych świadectw kultury egipskiej można wnioskować o wierze Egipcjan w istnienie hierarchii wśród zmarłych, począwszy od królów, a kończąc na zwykłych zmarłych. W religii egipskiej obecne jest także poddanie zmarłych osądowi trybunału, tworzonego przez bogów i Ozyrysa. Wobec niego zmarły musiał odpowiadać na pytania dotyczące popełnienia poszczególnych grzechów za życia ziemskiego. „Dowodem” na uczciwe życie lub przeciwnie - nieprawe

29 Szerzej zob. A. Ćwiek, Religia Egiptu, dz. cyt., s. 95-98; N. Grimal, Dzieje..., dz. cyt., s. $114-116$.

30 Szerzej zob. N. Grimal, Dzieje..., dz. cyt., s. 133-146. 
miało być ważenie serca zmarłego. Po nim następował wyrok dający wieczne szczęście lub unicestwienie ${ }^{31}$.

Jak można zauważyć w wierzeniach egipskich widoczna jest koncepcja wędrówki zmarłego po zaświatach, prowadząca do stanięcia przed trybunałem moralności i poddania się jego osądowi. Równocześnie można stwierdzić, że pewnego rodzaju uprzywilejowanie władcy odnośnie do możliwości wiecznego szczęścia zostaje rozszerzone z czasem także na zwykłych śmiertelników, którzy aby dostąpić przebywania $z$ bogiem Re, musieli otrzymać w procesie mumifikacji ,nowe ciało" sah, oznaczające szlachetność i dostojeństwo.

\section{Kultura fenicka}

Warte analizy wydaje się również spoglądnięcie na kwestię życia pośmiertnego w krainie leżącej na północ od Egiptu, na przeciwległym wybrzeżu Morza Śródziemnego. Mowa o Fenicji, która stanowiła wąski pas wybrzeża, rozciągający się od gór Libanu na wschodzie, od gór Karmel na południu, aż po Ras Shamra (okolice Ugarit) na północy (obecnie część Libanu i Syrii). Takie ukształtowanie sprzyjało powstawaniu miast-królestw, rządzonych niezależnie od siebie. Z pewnością był to jeden z czynników, który zdecydował o specyfice kultury fenickiej. Zanim jednak przyjęto określanie tego terenu nazwą Fenicja, stanowił po prostu część wielkiej krainy Kanaanu. Wielkiej, bo rozciągającej się od Egiptu po Syrię i Zajordanię na wschodzie. Określenie „Fenicja” wywodzi się od Greków i występuje praktycznie tylko w ich świadectwach ${ }^{32}$.

System wierzeń Fenicjan znany jest m.in. z inskrypcji fenickich i punickich, ale i dzięki pisarzom greckim, którzy zabarwili przekaz własnym sposobem rozumienia

31 Szerzej zob. A. Ćwiek, Religia Egiptu, dz. cyt., s. 98-102; N. Grimal, Dzieje..., dz. cyt., s. $147-148$.

32 Zob. Fenicja, red. P. Juszczak, Warszawa 2007, s. 8-11 (Mitologie Świata). Jeśli chodzi o pochodzenie Fenicjan, to trudno tu jednoznacznie dokonać rozstrzygnięcia. Herodot na przykład wskazuje na rejon Morza Czerwonego, jako teren, skąd przybyli Fenicjanie, jednak to wydaje się mało prawdopodobne. Inni starożytni geografowie natomiast mówią o Zatoce Perskiej. Po wspomnianych już „najazdach Ludów Morza”, skutkujących wycofaniem się do własnych granic Egiptu, powstała w Syro-Palestynie pustka polityczna, którą szybko zaczęły zagospodarowywać miasta-państwa. $\mathrm{Na}$ ten czas przypada między innymi powstanie królestwa Izraela i państewek aramejskich, a także uzyskanie swobody politycznej i kulturowej przez miasta fenicyjskie. Trzeba jednak zaznaczyć, że kultura Fenicji nie wzięła się z próżni, lecz była oparta na dziedzictwie Kananejczyków. Dalsze informacje na temat historii Fenicji znane są z dzieł m.in. Józefa Flawiusza i Herodota. Według jednej z nich mieli mieć oni znaczący wkład w stworzenie i rozpowszechnienie alfabetu, a według innych źródeł ich znaczący wkład w kulturę światową miał polegać na odkryciu purpurowego barwnika, który wykorzystywano do produkcji purpury. O innych talentach Fenicjan wspominają także karty Starego Testamentu, wymieniając m.in. wyroby ze złota, srebra, brązu i tkaniny purpurowe i kamazynowe (2 Krn 2, 6). Zob. Fenicja, [w:] A. Tschirschnitz, Dzieje ludów biblijnych, cz. VI: Dzieje państw i plemion starożytnej Syrii i Palestyny, Warszawa 1994, s. 139-145; Fenicja, dz. cyt., s. 10-22. 
kultu religii fenickiej. Stąd widoczne w tych ostatnich idee pochodzące $\mathrm{z}$ greckiej i hellenistycznej kultury. Wystarczy dokonać porównania panteonu bóstw greckich i fenickich. Religię Fenicjan charakteryzuje dodatkowo zróżnicowanie co do czczonych bóstw, w zależności od poszczególnych miast. Jednakże w pewnym momencie pojawia się idea najwyższego boga, niewykluczająca oczywiście wiary $\mathrm{w}$ inne bóstwa, a więc politeizm $\mathrm{z}$ ograniczoną formą monoteizmu. Być może czynnikiem wpływającym na to zbliżenie do monoteizmu były kontakty Fenicjan z Izraelem w okresie przedasyryjskim. Dodatkowo takie zbliżenie wyżej wymienionych dwóch kultur mogło być ułatwione posługiwaniem się przez nich podobnymi językami. Jeśli chodzi natomiast o ideę ożywienia po śmierci, to można ją odnaleźć w święcie Adonisa w Byblos ${ }^{33}$. Zagadnienie to poruszają także mity o walce Baala (bóg płodności i wegetacji) z Motem (bóstwem podziemi i śmierci). Według nich przegrana bóstwa wegetacji z siłami ciemności oznaczała obumarcie w przyrodzie, prowadząc do zmartwychwstania na wiosnę. Kolejnym bogiem, który umierał i zmartwychwstawał w czasie równonocy wiosennej, był Melkart (bóg słońca), czczony w Tyrze. Ten jednak umierał w płomieniach, ale i z nich się odradzał. W oczach Greków był on podobny do Heraklesa, a nawet mitycznego Feniksa ${ }^{34}$.

Rolę przewodniczki w zaświatach pełniła bogini Tanit, którą wspominają inskrypcje punickie, natomiast w Ugarycie bogiem podziemi był Reszef ${ }^{35}$. Ciekawą funkcję w religii fenickiej przypisywano Refaitom (prawdopodobnie ubóstwieni monarchowie), przebywającym w zaświatach pod postacią cienia, w inskrypcjach fenickich i punickich określanym jako „boskie dusze” lub „boskie cienie”. Termin ten spotykamy także w Biblii, odnośnie do pewnej kategorii zmarłych (Ps 88, 11). Podobnie jak w Biblii, również u Fenicjan występuje pojęcie szeolu - na określenie miejsca przebywania duszy człowieka po śmierci ${ }^{36}$.

Na podstawie tych wiadomości można stwierdzić, że ideę zmartwychwstania w ujęciu fenickim należy rozumieć jako cykliczny powrót do umarłych bóstw. Cykliczność tych wydarzeń stanowić miała przyczynę zmieniającej się przyrody. Nie jest to więc nauka, która choćby w przybliżeniu była podobna np. do Egipcjan, u których pojawia się myśl wiecznego życia po śmierci i mającego w nim udział zastępczego, nowego ciała człowieka.

33 Zob. A. Mrozek, Religia Fenicjan, [w:] Religie starożytnego Bliskiego Wschodu, dz. cyt., s. $290-294$.

34 Zob. Fenicja, dz. cyt., s. 49-50, 54-55.

35 Zob. tamże, s. 62-63, 65.

36 Zob. tamże, s. 82-83. 


\section{Tradycja perska}

Kultura perska jest kolejną, z którą spotkał się Izrael w ciągu swoich dziejów. Początkowym miejscem jej formowania był teren Wyżyny Irańskiej, położonej na wschód od Mezopotamii. Duży wpływ na jej kształt mieli Elamici, którzy nieco później od wspomnianych już w tym opracowaniu Sumerów mogli cieszyć swą kolejną zdobyczą intelektualną - pismem. Historia Elamitów naznaczona jest licznymi wojnami z mezopotamskimi sąsiadami. Dopiero w drugim tysiącleciu przed Chr. pojawienie się aryjskich, koczowniczych ludów Medów i Persów, z których pierwsi zajęli tereny na południe od Morza Kaspijskiego, drudzy natomiast osiedlili się jeszcze bardziej na południe, na wschód od Elamitów, doprowadziło do zachwiania dotychczasowej sytuacji. Oczywiście na stworzenie swoich wielkich imperiów wspomniane plemiona aryjskie potrzebowały czasu, ale już w wieku VIII przed Chr. państwo Medów ze stolicą w Ekbatanie stało się zagrożeniem dla wielkiej Asyrii. Po podbiciu Persów w VII wieku przed Chr. przez syna medyjskiego króla Delokesa, Fraorresa, Medowie, walcząc przeciwko Asyrii, spotkali się ze Scytami, którzy najpierw opanowali Asyryjczyków, a następnie samych Medów ${ }^{37}$.

Wzmianka o Scytach w tym miejscu nie jest przypadkowa, gdyż ich kulturę charakteryzowała bardzo specyficzna tradycja kultu zmarłych, przejawiająca się w tworzeniu dla nich grobów (kurhanów ${ }^{38}$ ), do których składano, jak przystało na ludy wojownicze, bogato zdobione elementy uzbrojenia i uprzęż końską. Co ciekawe, groby te pozostawiali oni jedynie tam, gdzie pozostawali na dłużej, co poniekąd wskazuje na to, jak ważną sprawą dla nich była troska o zmarłych, których balsamowano, a wokół nich ustawiano złote naczynia z jedzeniem i piciem, wyrażając przez to wiarę $\mathrm{w}$ dalszą ich egzystencję po śmierci ${ }^{39}$. Jednakże dominacja Scytów nie trwała zbyt długo, Medowie pokonali Asyrię. To zmieniło diametralnie układ sił, a co za tym idzie i wpływ na kulturę ze strony poszczególnych ludów $\mathrm{w}^{40}$. Ostatnim władcą, który odegrał bardzo istotną rolę w zhellenizowaniu kultury perskiej, był Aleksander Wielki, król Macedonii.

37 Szerzej zob. T. Jelonek, Kultura perska a Biblia, Kraków 2010, s. 9-12.

38 Kurhany miały stanowić obraz kręgu kosmicznego, stąd w swej formie nawiązywały do kręgu, góry oraz kopuły. Jako centrum sakralne, łączące niebo z ziemią, były początkiem drogi dla zmarłych, która prowadziła ich do szczęśliwej wieczności. Zob. A. Leligdowicz, Scytowie, Warszawa 2002, s. 10 (Starożytne Cywilizacje: Podróż przez Tysiąclecia, 51, red. B. R. Zagórski).

39 Zob. tamże, s. 11-12, 15, 19.

40 W połowie VI wieku do głosu doszli Persowie, dzięki działaniom Cyrusa Drugiego Starszego (559-530 przed Chr.), który połączył w swych rękach Medię i Persję. Przez jego liczne podboje Persja weszła w kontakt $\mathrm{z}$ wieloma królestwami i kulturami. Do podbitych terenów należy zaliczyć: wschodnie prowincje, jak Partię, Hyrkanię i Armenię, następnie Lidię, część Anatolii, Babilonię, Syrię, Fenicję i część Arabii. Następnie już po jego śmierci wpływy perskie rozszerzyły się na Egipt, część Indii i dalsze tereny Anatolii. Koniec rządów władców perskich był nacechowany 
Jak można zauważyć, kultura Persji znajdowała się pod wpływem różnych tradycji kulturowych, jak choćby te najważniejsze: aryjska, indoeuropejska, egipska, hellenistyczna, asyryjska. Jednakże należy podkreślić, że największą swobodą kulturalną i religijną, czyli tzw. polityką pobłażliwości przy równoczesnym istnieniu perskiej władzy zwierzchniej, podbite ludy cieszyły się za panowania Cyrusa Drugiego Starszego i Dariusza Wielkiego (522-486 przed Chr.), oczywiście w miarę ich lojalności względem władcy. W ten sposób na terenie Persji miano do czynienia z niespotykaną wręcz wcześniej różnorodnością wierzeń i kultur, które przecież nie pozostawały obojętne na siebie, ale były ze sobą konfrontowane i wyznaczały kierunek rozwoju cywilizacji perskiej ${ }^{41}$.

Najstarsze wierzenia Persów były bardzo podobne do tych, które reprezentowały inne ludy starożytne. Chodzi oczywiście o wiarę w istnienie życia pozagrobowego. Ważną rolę w tym względzie odgrywał w mitologii perskiej bóg ładu i sędzia w zaświatach, Mitra, który osądzał dusze zmarłych. O jego przymiotach i atrybutach można dowiedzieć się z Awesty, świętej księgi zawierającej teksty religijne wyznawców mazdaizmu ${ }^{42}$ i zaratusztrianizmu (zoroastryzmu) ${ }^{43}$. Państwowy status zaratusztrianizmu pozwolił jeszcze bardziej umocnić kult Mitry, jako jednego z jachazatów (czczonych), czyli nadnaturalnych istot, będących upersonifikowaniem idei i żywiołów ${ }^{44}$.

Dusza zmarłego według wierzeń starożytnych Irańczyków miałaby błądzić po świecie przez trzy dni po śmierci, aby potem odejść w zaświaty. To od rodziny i jej ofiar składanych dla zmarłego zależało, jak będzie funkcjonował w zaświatach. Obowiązek składania ofiar spoczywał w pierwszym rzędzie na rodzinie, a także na spadkobiercy majątku zmarłego. W tym ostatnim przypadku zobowiązanie wynosiło trzydzieści lat. Podobnie jak u wspomnianych Scytów, zmarłemu ofiarowywano jadło i odzienie. W przeciwnym razie jego cień poruszał się nagi i zmarznięty. Dla nas szczególnie istotne jest przekonanie wiernych, iż trzeciego dnia, kiedy dusza przemierza „most dzielący światy”, dochodzi do indywidualnego sądu nad zmarłym. W tym też dniu dusza zmarłego była najbardziej narażona na działanie złych duchów, krążących po ziemi, stąd też potrzebowała ona czegoś w rodzaju rytualnej ochrony w postaci krwawej ofiary, po której przez trzydzieści dni składano codzienne ofiary, zakończone kolejną krwawą ofiarą. Po nich następowały ofiary miesięczne, a po upływie roku tylko roczne ${ }^{45}$.

licznymi powstaniami, osłabiającymi imperium Persów. Szerzej zob. T. Jelonek, Kultura perska..., dz. cyt., s. 12-31.

${ }^{41}$ Zob. K. Sidor, Bogowie, magowie i nafta, Warszawa 1971, s. 30.

42 Pierwsza perska religia, która rozwinęła się z pierwotnych kultów aryjskich.

43 Zob. Religie świata. Encyklopedia, red. J. Rawicz i in., Kraków 2005, s. 530.

44 Zob. M. Składankowa, Mitologia Iranu, Warszawa 1989, s. 369.

45 Zob. K. Jakubiak, Religia Iranu, [w:] Religie starożytnego Bliskiego Wschodu, dz. cyt., s. $317-318$. 
Kwestia wiary w życie pozagrobowe pojawia się także w kontekście jednego $\mathrm{z}$ siedmiu najważniejszych świąt $\mathrm{w}$ kalendarzu, ustanowionych już po objawieniach Zaratusztry. Chodzi w tym przypadku o święto równonocy wiosennej ( $\mathrm{Ha}$ maspatmaedeja), w ramach którego oddawano cześć duszom zmarłych (frawasz$t i)$. Nieznane są bliższe informacje na temat tego rytuału, lecz przypuszcza się, że przypominały znane w słowiańskim kręgu kulturowym obrzędy dziadów. Będąc przy temacie świąt w kulturze perskiej, trzeba także zwrócić uwagę na obchody NuwRuz, tzn. święta Nowego Roku. Niosło ono bowiem ze sobą wiarę eschatologiczną, według której koniec świata z pewnością nastąpi, a wraz z nim nadejdzie ostateczna konfrontacja dobra ze złem. Czas, w którym nastąpi definitywny triumf dobra nad złem, będzie pierwszym dniem wiecznego życia ${ }^{46}$.

Pojęcia zmartwychwstania jednak tu nie spotykamy. Niemniej wymiar filozoficzno-etyczny religii perskiej choćby w odniesieniu do zagadnień eschatologicznych prezentuje wysoki poziom rozwoju. Trudno tu określić wpływ, jaki mogła mieć ona na przykład na judaizm, czy też w późniejszym okresie na chrześcijaństwo ${ }^{47}$, lecz wydaje się mało prawdopodobne, żeby była mu całkiem obojętna. Dwie cechy religii perskiej: trwałość i umiejętność kohabitacji z innymi kulturami, wierzeniami, nie wyłączając religii Izraela, sprawiły, że miała ona zapewne pewien wpływ na nie, pełniąc być może rolę bodźca do rozmyślań i rozwoju określonych kwestii $\mathrm{w}$ tychże religiach ${ }^{48}$. Oczywiście nie należy przeceniać wpływu idei zaratusztrianizmu na myśl biblijną w judaizmie czy później chrześcijaństwie. Z pewnością słuszniejsze wydaje się tu mówienie o podobieństwach między pewnymi zagadnieniami w wyżej wymienionych religiach: ostateczne zwycięstwo dobra, sąd ostateczny i związane z nim zmartwychwstanie ciał, podobieństwo roli Saoszjanta zesłanego na ziemię przez Ahura Mazdę ${ }^{49}$ oraz Chrystusa jako Mesjasza ${ }^{50}$.

46 Zob. tenże, Religia Iranu, dz. cyt., s. 322-324.

47 Pod uwagę bierze się tutaj chrześcijan mieszkających w II wieku po Chr. na terenie Persji, czyli w czasie ostatecznego kształtowania się Awesty. Pojawiła się wówczas sekta manichejczyków, których założyciel, perski reformator religii, Mani łączył elementy zaratusztrianizmu z nauką chrześcijańską. Zob. T. Jelonek, Kultura perska ..., dz. cyt., s. 141.

48 Zob. http://geopolityka.net/religie-starozytnej-persji/(28.04.2014).

49 Nazwa bóstwa powstała z połączenia dwóch słów: Ahura (Pan), w staroindyjskim pokrewnym wyrażeniem jest asura, i mazda (mądry). Jego przymiotem była wszechwiedza, którą zazwyczaj w tym kręgu kulturowym przypisywano bogu nieba. Z Awesty dowiadujemy się też, że był on bogiem Stwórcą. Zob. M. Boyce, Ahura Mazda, [w:] Encyclopcedia Iranica, ed. E. Yarshater, t. 1, London 1985, s. 684-687; O. G. von Wesendonk, Das Weltbild der Iranier, München 1933, s. 69.

50 Zob. T. Jelonek, Kultura perska..., dz. cyt., s. 152. 


\section{Bibliografia}

Arnold S., Kurkiewicz W., Tatomir A., Żurawski W., Dzieje świata. Chronologiczny przegląd wydarzeń, Warszawa 1990.

Baran G. M., Los czlowieka po śmierci w wierzeniach ludów ościennych dawnego Izraela, „Scripturae Lumen” 2010 nr 2, s. 137-160.

Bartnik C. S., Dogmatyka katolicka, t. 1, Lublin 1999.

Boyce M., Ahura Mazda, [w:] Encyclopaedia Iranica, ed. E. Yarshater, t. 1, London 1985.

Bravo B., Wipszycka E., Historia starożytnych Greków. Okres hellenistyczny, t. 3, Warszawa 1992.

Ćwiek A., Religia Egiptu, [w:] Religie starożytnego Bliskiego Wschodu, red. K. Pilarczyk, J. Drabina, Kraków 2008, s. 27-176.

Fenicja, red. P. Juszczak, Warszawa 2007 (Mitologie Świata).

Gilgamesz. Epos starożytnego Dwurzecza, tt. R. Stiller, Warszawa 1980.

Golzio K. H., Der Tempel im Alten Mesopotamien und Seine Parallelen in Indien. Eine Religionshistorische Studie, Hamburg 1983 (Beihefte der Zeitschrift für Religions und Religionsgeschichte, 25).

Grimal N., Dzieje starożytnego Egiptu, Warszawa 2004.

Gurney O. R., The Sultantepe tablets (continued), VII: The myth of Nergal and Ereshkigal, „Anatolian Studies” 10 (1960), s. 105-131.

Herodot, Dzieje, tt. S. Hammer, Warszawa 1959.

Hudzikowski M., Religie starożytnej Persji, 28.04.2014, http://geopolityka.net/religiestarozytnej-persji (28.04.2014).

Jakubiak K., Religia Iranu, [w:] Religie starożytnego Bliskiego Wschodu, red. K. Pilarczyk, J. Drabina, Kraków 2008.

Jelonek T., Kultura Mezopotamska a Biblia, Kraków 2009.

Jelonek T., Kultura Perska a Biblia, Kraków 2010.

Kemp B. J., Starożytny Egipt. Anatomia cywilizacji, tł. J. Aksamit, Warszawa 2009.

Leligdowicz A., Scytowie, Warszawa 2002 (Starożytne Cywilizacje: Podróż przez Tysiąclecia, 51).

Marciniak M., Historia starożytnego Egiptu, [w:] Starożytny Egipt, red. A. Szczudłowska, Warszawa 1978.

Mrozewicz L., Historia powszechna. Starożytność, Poznań 1999.

Religie świata. Encyklopedia, red. J. Rawicz, Kraków 2005.

Shaw I., The Oxford history of ancient Egypt, Oxford 2000.

Sidor K., Bogowie, magowie i nafta, Warszawa 1971.

Składankowa M., Mitologia Iranu, Warszawa 1989.

Sołtysiak A., Religie Mezopotamii, [w:] Religie starożytnego Bliskiego Wschodu, red.

K. Pilarczyk, J. Drabina, Kraków 2008, s. 111-176.

Starożytni Egipcjanie, red. J. Cieślewska, Warszawa 2007 (Mitologie Świata).

Tschirschnitz A., Dzieje ludów biblijnych, cz. VI: Dzieje państw i plemion starożytnej

Syrii i Palestyny, Warszawa 1994. 
Wesendonk O. G. von, Das Weltbild der Iranier, München 1933.

Wilkinson T. A. H., Early dynastic Egypt, London, New York 1999.

Zinkow L., Imhotep - „Twórca cywilizacji”, „Episteme. Czasopismo Naukowo-Kulturalne" 2012 nr 16 t. 1, s. 5-20.

Zmartwychwstanie w mitach i religiach, http:/www.opoczno-top.pl/artykul,Zmartwychwstanie_w_mitach_i_religiach,11998.html (02.05.2014), (artykuł ukazał się również w wydaniu nr 13 [820] „Tygodnika Opoczyńskiego” 29.03.2013).

\section{Streszczenie}

Spojrzenie na religie Bliskiego Wschodu pod kątem wiary w zmartwychwstanie ukazuje, że najbardziej rozwinięta wiara dotycząca życia po śmierci występuje w kulturze egipskiej i perskiej. W pierwszej wyraźne jest przekonanie o konieczności posiadania „nowego ciała” w celu przebywania w obecności boga słońca Re, natomiast w drugiej, zwłaszcza biorąc pod uwagę zaratusztrianizm, wyraźnie ukazuje się postać Saoszjanta, mającego poprowadzić ludzi do ostatecznego zwycięstwa z siłami zła i ustanawiającego bezpośrednie królestwo Ahura Mazdy. Ciekawa jest także w wierzeniach Persów wzmianka na temat trzeciego dnia, jako czasu przejścia duszy zmarłego z „tego świata” i stanięcie przed indywidualnym sądem. Ten ostatni ma także miejsce $\mathrm{w}$ wierzeniach egipskich, według których jest on momentem moralnego rozliczenia zmarłego z ziemskiego życia. W przypadku kultury mezopotamskiej i fenickiej, choć istniała w nich wiara $\mathrm{w}$ pewną formę nieustannego życia po śmierci w podziemiach, nieśmiertelność dotyczyła jedynie bóstw lub monarchów, a idea ,zmartwychwstania” jako odrodzenia dotyczyła wyłącznie corocznego odrodzenia przyrody, które zgodnie z wierzeniami zawdzięczano działaniu bóstw płodności.

\section{Słowa kluczowe}

zmartwychwstanie, życie po śmierci, kultura Mezopotamii, kultura Egiptu, kultura Fenicjan, religia Persów, zaratusztrianizm

\section{Summary}

\section{The idea of resurrection in the religions of the Middle East}

The purpose of this essay is to present the idea of the resurrection in the major cultures of the Middle East. In its presentation was used a reference to the biblical tradition that shows the similarities rather than the genealogy of the biblical eschatological thought. In the presentation of the culture of Mesopotamia it is noticed some exclusivism, as for the issue of immortality, which was participated only by a few, however, some kind of existence of dead in underworld was assumed.

Certain development of the idea brings the Egyptian and the Persian culture, introducing motives of journey of dead and the posthumous court as a moral evaluation of earthly 
life, as well as, the possibility of attainment an honor to be in presence of gods, as a reward for an honest life. All cultures, however, not excluding the Phoenician, characterize a belief in the necessity of the burial of the human body, as one of the conditions for peace of soul of the dead.

\section{Keywords}

the resurrection, life after death, the culture of Mesopotamia, culture Egyptian, culture Phoenicians, Persian religion, the zoroastrianism 